\title{
Budowanie i trwanie - karty ze średniowiecznych dziejów świątyni parafialnej Starego Miasta Torunia, obecnej katedry pw. św. Jana Chrzciciela i św. Jana Ewangelisty*
}

T iczne przekształcenia architektury i zmiany wyposażenia fary Starego Miasta Torunia można odczytywać jako świadectwa burzliwych przemian historycznych i niespokojnych poszukiwań artystycznych, ale też jako wyraz sił duchowych - woli przetrwania i trwania komuny miejskiej i jej kościoła, stanowiących zwartą strukturę, „układ spoisty”. Badania historyków, historyków sztuki, archeologów i konserwatorów ostatnimi laty

* Artykuł jest tekstem referatu wygłoszonego na konferencji pt. „W trosce o katedrę toruńską", związanej z uroczystościami erygowania katedry św. Janów w Toruniu i dedykowanej JE Ks. Biskupowi Andrzejowi Suskiemu w roku jubileuszowym 25-lecia sakry biskupiej, zorganizowanej w Toruniu w dniu 25 marca 2011 r. Autorka serdecznie dziękuje panu Andrzejowi Skowrońskiemu, autorowi fotografii, za zgodę na prezentację zdjęć na sesji i na wykorzystanie ich w niniejszej publikacji. 
coraz mocniej akcentują ten aspekt dziejów świątyni ${ }^{1}$. Ujawniają, że na każdym etapie budowania materialnej substancji była manifestowana wola trwania Kościoła jako struktury jednoczącej i reprezentującej komunę miejska. Używano w tym celu artystycznego języka obrazu. I on nas będzie prowadził.

W najwcześniejszym okresie formowania się miasta, po translokacji ze Starego Torunia w 1236 roku, świątynia wtapiała się w zjawiska kulturowe zachodzące w „młodej” osadzie miejskiej. Władca feudalny, jak również mieszkańcy skupiali się na zagospodarowaniu i zorganizowaniu wytyczonej przestrzeni jako miejsca fizycznej i duchowej egzystencji. Kościół parafialny był instytucją i budowla pierwszej potrzeby i pierwszoplanowym zadaniem budowlanym - sakryfikował bowiem cały obszar miejski, a starych i nowych mieszkańców symbolicznie chronił od złego. Dlatego też już w początkowej fazie kształtowania się lokacyjnego układu urbanistycznego został wydzielony plac pod jego budowę. Materialną substancję z tego okresu trudno jest jednak uchwycić (il. 1). Archeologiczne relikty znajdują się w obrębie obecnego prezbiterium, poniżej posadzki, i pozwa-

1 W. Rozynkowski, Omnes Sancti et Sanctae Dei. Studium nad kultem swietych w diecezjach pruskich państwa zakonu krayżackiego, Malbork 2006; S. Kobielus, Treści ideowe plyty nagrobnej matżonków von Soest z kościoła św. Jana w Toruniu, „Acta Universitatis Nicolai Copernici. Zabytkoznawstwo i Konserwatorstwo", 1991, t. 17, s. 95-123; M. Kutzner, Die spätmittelalterliche Ausstattung der Marienkirche als Ausdruck der intellektuellen Empfindsamkeit und Religiosität der Danziger Bürger im augehenden Mittelalters, [w:] Die Sakrale Backsteinarchitektur des südlichen Ostseeraums - der theologischen Aspekt, hrsg. von G. Eimer, E. Gierlich (Kunsthistorische Arbeiten der Kulturstiftung der deutschen Vertriebenen, Bd. 2), Berlin 2000, s. 131-155; H. Manikowska, Religijnośc miejska, [w:] Ecclesia et civitas. Kościót $i$ aycie religijne w mieście średniowiecznym, pod red. H. Manikowskiej, H. Zaremskiej, Warszawa 2002, s. 11-36; M. Woźniak, Die Kirchen der Stadt Thorn. Beiträge zur Liturgie im Deutschordensland Preussen, [w:] Die Sakrale Backsteinarchitektur, s. 179-194; Kościót pw. św. Jana Chraciciela i św. Jana Ewangelisty w Toruniu w okresie średniowiecza jako wizualizacja śmiadomości społecznej, [w:] Drieje i skarby kościoła śmiętojańskiego w Toruniu, pod red. K. Kluczwajd, M. Woźniaka, Toruń 2002, s. 119-177; E. Pilecka, Die Pfarrkirche St. Johannis zu Thorn als Abbild der sozialen Sinnenart des mittelalterlichen Bürgertums, [w:] Licht und Farbe in der mittelalterlichen Backsteinarchitektur des südlichen Ostseeraums, hrsg. von E. Badstübner, G. Eimer, E. Gierlich, M. Müller (Studien zur Backsteinarchitektur, Bd. 7, hrsg. von E. Badstübner, D. Schumann), Berlin 2005, s. 408-437. 
lają sądzić, że tzw. I kościół stanowił ceglaną budowlę salową, wzniesioną na fundamencie z kamieni polnych, od strony wschodniej zamkniętą trójbocznie. Wnętrze było nieduże, jednoprzestrzenne, zapewne sklepione, podzielone na przęsła (?), wyłożone podłogą z desek - czyli utylitarne, skromne, przeznaczone na potrzeby niezbyt licznej, choć pełnej nadziei na przyszłość gminy. Bryłę opinały skarpy, a ściany i przypory obiegał cokół z profilowanym gzymsem z glazurowanej, cegły (il. 2). Choć nieduży, kościół musiał znacznie wyróżniać się w zabudowie miejskiej swoimi gabarytami². Trudno dociekać rodowodu artystycznego takiego rozwiązania architektonicznego - było zbyt proste, utylitarne, niemal pozbawione detalu. Wykorzystanie cegły glazurowanej może jednak wskazywać na dążenie do podniesienia reprezentacyjności budynku świątyni i sięgnięcie w tym względzie do koncepcji znanych z architektury ceglanej niżu nadbałtyckiego, gdzie chętnie używano takiej dekoracji, a i tradycja techniczna jej produkcji była ugruntowana ${ }^{3}$. Ta skromna budowla stanowiła jednakże przede wszystkim nośnik znaczeń. Musiała być odczytywana w uniwersalnych dla człowieka średniowiecza kategoriach, gdyż w tej epoce budynek kościoła zawsze rozumiano metafizycznie ${ }^{4}$. Widziano w nim obraz Królestwa Bożego oraz jego abrewiację - symboliczną wizję ówczesnego miasta i panujących w nim stosunków. Był znakiem urzeczywistniania się Państwa Bożego na ziemi. Wierni współtworzyli je przez kult sprawowany w świątyni. Manifestowali wiarę w jego trwanie i przetrwanie w ówczesnych, trudnych warunkach życia codziennego - tak potrzebną w początkach istnienia miasta na terytorium starć z pogańskimi plemionami pruskimi. Prosta architektura chroniła sprzęt niezbędny do sprawowania liturgii, obrazujący istotne prawdy teologiczne i budujaccy splendor liturgicznych obrzędów. Za jedyny zapewne relikt skromnego wyposażenia możemy

2 L. Grzeszkiewicz-Kotlewska, Badania archeologiczne prezbiterium kościoła śniętojańskiego w Toruniu w latach 1994-1995, [w:] Drieje i skarby kościoła świetojańskiego w Toruniu, s. 103-119.

3 Zob. Sztuka średnionieczna, [w:] A. Błażejewska, E. Pilecka, Drieje sætuki Torunia, Toruń 2009, s. 15-187.

4 G. Bandmann, Mittelalterliche Architektur als Bedeutungsträger, Berlin 1979; S. Kobielus, Niebiańska Jerozolima. Od sacrum miejsca do sacrum modelu, Ząbki 2004. 
uznać czaszę chrzcielnicy odlanej z brązu ${ }^{5}$ (il. 3). Wykonał ją najpewniej warsztat „wędrowny”, wykazujący pewną znajomość dekoracji dzwonów $z$ terenu Saksonii i Turyngii. Nie to jest jednak istotne, ale wizualne znaki na tej czaszy - główki lwów, motyw arkadek, majuskułowe litery, które nie stanowiły tylko zdobienia, lecz także wiązały się semantycznie z funkcją naczynia - z sakramentem chrztu, rozumianego jako „przejście” ze śmierci do życia. Jak w każdym momencie granicznym intensyfikowało się wówczas działanie sił dobra i zła. Symbolikę związaną ze złem, szatanem oddają tu główki lwów; pełnią one też funkcję apotropeiczną. Funkcję magiczna, swoistego zaklęcia wiążącego złe moce, pełni zaś fryz literowy z łacińskiej majuskuły, niebudujący logicznego tekstu, a jedynie sugerujący inskrypcję. Ostrołuczne arkadki to odwołanie do semantyki architektury, w tym przypadku symbolizującej Raj, czyli Miasto Niebieskie - Jeruzalem lub Świątynię Bożej Mądrości, a tą staje się - symbolicznie - każdy nowo ochrzczony. Wyposażenie odzwierciedlało więc także wolę przetrwania i trwania w młodym mieście, umacniał ją Kościół i jego sakramenty.

Zmiany w wyglądzie świątyni nastapiły po połowie XIII wieku - wraz z rozwojem Torunia, zwiększeniem się liczby jego ludności, krzepnięciem struktur miejskich, poszerzaniem samorządności oraz rozbudową na terytorium państwa zakonnego w Prusach sieci parafialnej. Jak na rozwijająca się prężnie gminę tzw. II kościół był wznoszony stosunkowo późno, bo po ponad 60 latach istnienia poprzedniego. Koncepcja jego architektury, całkowicie odmiennej od pierwszej realizacji, wynikała ze świadomości odniesionego sukcesu - trwania zapewnionego już dzięki sprzyjającym okolicznościom. Ta „druga” świątynia - w znacznej części zachowana w istniejącej strukturze murów - była niską, trójnawowa, trójprzęsłową (dziewięciopolowa) hala, tzw. typu westfalskiego, na planie kwadratu, z nawami równej wysokości, prostokątnym chórem od wschodu, małą zakrystią i wieżą od północy. Z tego czasu przetrwały: obecny chór, trzy pary filarów nawy (do połowy obecnej wysokości) i odpowiadające im pólośmioboczne półfilary na ścianach naw bocznych oraz ślady nasad sklepiennych (il. 4a, b, c, d).

5 M. Jakubek-Raczkowska, Trzynastowieczna chrzcielnica z kaplicy Kopernika w kościele pw. św. Jana Chraciciela i sw. Jana Ewangelisty w Toruniu, [w:] Dicieje i skarby kościota śmietojańskiego w Toruniu, s. 237-255. 
Kwestia dyskusyjna pozostaje to, czy prace przy budowie II kościoła rozpoczęto od wznoszenia korpusu, czy prezbiterium ${ }^{6}$ - wiemy jednakże, że ukończono je w końcu lat 30. XIV stulecia. Chór prawdopodobnie nieco wcześniej - około 1300 roku. Przemawiaja za tym talerzowe zworniki sklepienne, imposty półfilarów i inne detale architektoniczne (il. 5a, b, c, d). Maswerki w oknach prezbiterium mają cechy jeszcze dawniejsze - z przełomu trzeciej i czwartej ćwierci XIII wieku. O ukończeniu prac w tych latach może świadczyć także brązowa kołatka znaleziona w południowym portalu chóru (?), datowana na lata 1325-1350 (il. 6).

Korpus nawowy realizowano zasadniczo w drugiej ćwierci XIV wieku, a w 1349 roku są wzmiankowane pierwsze dwie kaplice od wschodu: pw. Bożego Ciała (od nazwiska fundatora zwana Heinricha Rockendorfa lub Rockendorfów) i pw. św. Krzyża (Nicolausa Pfafkorna). Ówczesna realizacja nie miała już charakteru małego oratorium, ale świątyni z „,nowym” programem. Język form detali architektonicznych nawiązywał do architektury far miast nadbałtyckich: Lubeki, Wismaru, Bremy, świątyń z terenu Szlezwika-Holsztynu i Meklemburgii. Genezę dziewięciopolowej hali z prosto zamkniętym chórem wyprowadzano z modelu ukształtowanego na terenach Westfalii, a zmodyfikowanego pod wpływem hal śląskich i właśnie lubeckich ${ }^{7}$. Architektura ta niosła czytelny dla miejskiej społeczności wykład treści teologicznych. Prosty plan chóru, klarowne proporcje, dekoracja zworników itp. służyły pełniejszemu oddaniu obrazu Kościoła - Eklezji ${ }^{8}$, trwałej i zwycięskiej. Natomiast oddzielona łukiem tęczy przestrzeń korpusu była na sposób symboliczny „demokratyczna” ze względu na zniesienie wysokościowej hierarchii przestrzeni naw; zrów-

6 T. Mroczko, Architektura gotycka na ziemi chetmińskiej, Warszawa 1980, s. 74 -99 .

E. Pilecka, Kościół pw. św. Jana Chrzciciela i św. Jana Ewangelisty w Toruniu wokresie średniowiecza jako wizualizacja świadomości społecznej, [w:] Dzieje i skarby kościoła świętojańskiego w Toruniu, s. 119-177. Ciekawostka potwierdzającą szerokie horyzonty ówczesnych mieszkańców miasta jest wnęka na „wieczną lampę” we wschodniej ścianie prezbiterium. Miała ona oświetlać przykościelne „miasto zmarłych” (cmentarz), a ma funkcjonalne odpowiedniki w XIII-wiecznej architekturze europejskiej, jak np. w tzw. Georgenchor (chórze św. Jerzego) w katedrze w Bambergu (okragły otwór) czy w katedrze w Ratyzbonie (ostrołuczna wnęka).

8 G. Bandmann, op. cit. 
nanie ich wysokości. Odpowiadała ówczesnej mieszczańskiej ideologii. Korpus o jasnych proporcjach jednakowych przęseł, z wieżą na osi, był jednocześnie obrazem Kościoła ziemskiego, a zarazem obrazem civitas - miasta. Wieża zachodnia nawiązywała do archetypicznego znaku feudalnej siły i demonstrowała umacniającą się pozycję ówczesnych władz municypalnych $\mathrm{w}$ relacjach z zakonną władzą terytorialną. Wykorzystany w korpusie wzorzec architektoniczny z bliskich komunie Starego Miasta centrów hanzeatyckich świadczył o poczuciu przynależności komuny do silnej, kupieckiej, pozaregionalnej wspólnoty interesów. Ten język form architektonicznych dowodzi, że budowie świątyni na tym etapie jej istnienia towarzyszyła świadomość okrzepłego trwania zarówno struktury lokalnego Kościoła, jak i miasta.

Gdy rozpoznajemy liczne już w tym czasie elementy wystroju i wyposażenia tej świątyni, widzimy zawartą w nich szeroką wykładnię prawd teologicznych, program eklezjologiczny i soteriologiczny, a przy tym większa skłonność do narracyjności w ukazywanych wątkach tematycznych, wiarę w trwałość i siłę Kościoła oraz jego opiekę nad gminą miejską. Z tego czasu zachowało się dużo elementów: począwszy od detali rzeźbiarskich (zworniki w chórze, wsporniki i służki sklepienne, malowidła ścienne i fragmentarycznie zachowane witraże) (il. 7). Zawarty w nich program ikonograficzny jest pełen nadziei; odnosił się do idei triumfu Kościoła i zadań Kościoła misyjnego, zbawczego. Zworniki z przedstawieniem Baranka Apokaliptycznego, symboli Czterech Ewangelistów, dekoracją z liści dębu mówią o triumfie Eklezji i jej nauce opartej na Ewangeliach. Styl tej rzeźby pozwala ją datować na lata tuż po roku 1300 i łączyć $z$ ważnym artystycznie kręgiem postrasburskim, co świadczy o sięganiu po europejskie wzory formalne (il. $5 \mathrm{a}, \mathrm{b}, \mathrm{c}, \mathrm{d}$ ). $\mathrm{Na}$ ścianie wschodniej chóru pojawiły się monumentalne postacie patronów kościoła, wzmacniające w wiernych poczucie pewności ich opieki. Z istotnych elementów wyposażenia zachował się monumentalny krucyfiks, który najprawdopodobniej, jako tzw. krucyfiks triumfalny, był centralnym elementem belki tęczowej, umieszczonej na granicy korpusu nawowego i prezbiterium 9 (il. 8). Przypuszczalnie z tego kościoła pochodzi

9 J. Raczkowski, Dawny krucyfiks triumfalny z kościoła swiętojanskiego w Toruniu, [w:] Drieje i skarby kościoła śmietojańskiego w Toruniu, s. 257-273; inne datowanie zob. w: Sztuka średniowieczna, s. 42. 
też krucyfiks procesyjny, znany obecnie pod nazwą krucyfiksu sądowego, $\mathrm{o}$ rodowodzie nadreńskim ${ }^{10}$. Zespołem tradycyjnie wiązanym z wyposażeniem fary są rzeźbione figury Maria Bolesna i Św. Jan Ewangelista (obecnie w Muzeum Okręgowym w Toruniu). Zachowane do dzisiaj murowane ołtarze przy filarach wydają się pochodzić także z czasu owego drugiego kościoła. Mają murowane w cegle stipes (skrzynie), z kamiennymi mensami (płytami) i prawdopodobnie ze „schowkami” w stipes ołtarzy. Do wnętrza fary prowadziły portale, wyposażone zapewne $\mathrm{w}$ drewniane, polichromowane drzwi z okuciami i kołatkami z brązu, co poświadcza wspomniana kołatka z głową lwa z drugiej ćwierci XIV wieku, być może pochodząca z reprezentacyjnego zachodniego portalu (il. 6). Szlachetna forma toruńskiego odlewu wskazuje, że gust lokalnego środowiska - około połowy XIV wieku - zwracał się ku warsztatom czynnym w miastach kwitnącej Hanzy (Kołobrzegu, Lubeki, Rostocku, Wismaru, Kilonii, Getyngi i Halberstadt). W tym drugim okresie położono wyraźnie nacisk na podnoszenie splendoru świątyni farnej, która ogniskowała uwagę władz i społeczności miejskiej. Była to światynia pewnego siebie i ufnego w przyszłość mieszczaństwa.

Z różnych przyczyn budowla weszła w fazę przekształceń po połowie XIV wieku (umownie określanych jako realizacja „trzeciego" kościoła). Znamienne, że nie realizowano nowego, całościowego projektu architektonicznego, jak w przypadku II kościoła, ale raczej wprowadzano zmiany dostosowywane do istniejącej struktury architektonicznej - może trochę wymuszone, bo konieczne ze względu na zniszczenia po pożarze miasta w 1351 roku. Skalę tych zniszczeń i zakres ówczesnej ingerencji trudno ocenić, gdyż ślady zatarła XV-wieczna przebudowa i późniejsze dzieje świątyni. Dyskusyjne pozostają nawet hipotezy o bazylikowym lub pseudobazylikowym rozwiązaniu korpusu ${ }^{11}$. Faktem jest odbudowa wieży na dawnym miejscu (?), obudo-

10 Sz̨uka średniowieczna, s. 42-43. Krucyfiksy procesyjne należały wówczas do podstawowego wyposażenia liturgicznego kościoła - umieszczane na drewnianym trzonku, były wnoszone na czele uroczystej procesji w chwili rozpoczęcia liturgii eucharystycznej, a w trakcie liturgii umieszczane przy ołtarzu lub bezpośrednio na mensie.

11 C. Steinbrecht, Die Baukunst des Deutschen Ritterordens in Preussen, Tl. 1: Die Stadt Thorn. Thorn im Mittelalter. Ein Beitrag zur Baukunst des Deutschen Ritterordens, Berlin 1885, sądził, że zasięg pożaru był duży; po pożarze miał pozostać jedynie chór i fi- 
wanie jej dwoma aneksami przedłużającymi nawy boczne, a także powiększenie zakrystii i wzniesienie pozostałych kaplic po stronie północnej (do 1374 roku ), a po okresie 1400-1407 również po południowej ${ }^{12}$. Jedynym źródłem mówiącym o tej fazie budowania jest dokument z 1361 roku - zapis 200 grzywien na odtworzenie wieży i kościoła oraz zezwolenie z 1388 roku na pochówek w świątyni osób wspierających budowę, co jest interpretowane jako data kończąca prace budowlane. Jeśli (jak chcą C. Steinbrech i T. Mroczko) korpus uzyskał przestrzeń pseudobazylikową lub bazylikowa, to możemy przyjąć, że działaniom tym przyświecała idea nawiązania do prestiżowego wówczas w ośrodkach hanzeatyckich modelu bazylikowej świątyni farnej, takiej, jakie były znane z Lubeki, Stralsundu, Rostocku, Greifswaldu, Wismaru i wielu innych miast nadbałtyckich ${ }^{13}$. Znamienne jednak jest, że nie podjęto próby zaktualizowania form architektonicznych, tj. rzutu, kształtu przekroju filarów, proporcji elementów przestrzennych wnętrza czy typu wieży, a wręcz zachowano skrzętnie detale z poprzedniej realizacji. Masyw wieży sprzężonej z kompartymentami dodanymi na przedłużeniu naw bocznych był - tak jak w świątyniach miast hanzeatyckich - świadomym przypomnieniem formy tzw. Westwerku, znanego z architektury kościołów władców feudalnych. Chodziło zapewne o symboliczne odwołanie się do znaku siły władzy - w naszym przypadku dotyczącym pozycji rady miejskiej w XIV-wiecznym Toruniu. W tych architektonicznych działaniach komunie miejskiej zależało na odnowieniu świątyni parafialnej, ale jednocześnie wydaje się, że prace prowadzone w drugiej połowie XIV wieku nie znajdowały się w centrum jej zainteresowań. Standaryzacja realizowanej koncepcji architektonicznej,

lary hali. W takiej sytuacji uważał, że odbudowano cały korpus jako pseudobazylikę i przedłużono go o jedno przęsło. Powtórzyła to T. Mroczko, op. cit., s. 209. Johannes Heise (1889) uważał, że została zniszczona wieża i sklepienia, a więc wzniesiono nową wieże, przedłużono korpus i zasklepiono bryłę. A. Semrau, Forschungen zur Bangeschichte der Johanniskirche in Thorn von 1250 bis 1500, „Mitteilungen Copernicus Verein”, 1913, H. 21, s. 1-28, uważał, że tylko wieża runęła, ale wzniesiono nowy, dłuższy korpus. Nie wspomina on o wysokości naw.

12 A. Semrau, op. cit., s. 1-28.

13 Jeśli przekształcono pierwotna, niską halę w pseudobazylikę, to byłoby to także nawiązanie do anachronicznych już w XIV w. rozwiązań pseudobazylikowych z terenu niżu nadbałtyckiego. 
wieloetapowość działań, koncentracja uwagi bogatych rodów mieszczańskich przede wszystkim na budowie poszczególnych kaplic i ich wyposażaniu - wskazują na zmniejszenie zainteresowania fara jako „całością” na rzecz partykularyzmu celów - urządzania własnych kaplic i „kątów” do modlitwy.

Od około połowy XIV wieku modyfikowano program wystroju chóru świątyni. Na wysklepki wschodniego i zachodniego przęsła zostały ,nałożone" malowane medaliony - po cztery w każdym przęśle (około 1350-1360 roku) (il. 9). W przęśle wschodnim znalazły się półpostaci: Chrystusa w nimbie krzyżowym, Najświętszej Marii Panny, św. Jana Chrzciciela i św. Jana Ewangelisty. W zachodnim przęśle medaliony z przedstawieniami czterech archaniołów - Strażnikón Tronu. Było to syntetyczne ujęcie tematu zwanego Deesis - akcentującego wstawiennictwo Marii i świętych w chwili Sądu Ostatecznego. Tak więc do wcześniejszej wykładni idei Niebiańskiej Jerozolimy na zwornikach został dodany temat soteriologiczny i eschatologiczny - przywołujący moment przejścia zbawionych do Niebiańskiego Jeruzalem i obcowania świętych. Powiązanie medalionów z postaciami świętych patronów na ścianie wschodniej zbudowało wielowarstwowy obraz Kościoła Triumfującego. Wykorzystano różne środki wyrazu artystycznego: malowidła, rzeźbę, detal architektoniczny, polichromię żeber. Rozbudowana wykładnia treści eklezjologicznych była czytelna dla ówczesnych mieszkańców miasta, a stopniowe poszerzanie programu stanowiło znamienne świadectwo woli i pewności trwania oraz chęci pozostawienia po sobie dziedzictwa. Na ścianie północnej chóru około 1380 roku zostało także namalowane rozbudowane ikonograficznie przedstawienie Ukrzyżowania na „乏уynym krzyżu” wyrastającym z boku Jessego i scena Sadu Ostatecznego (il. 10). Malowidło złączyło się we wspólny wykład o zbawieniu z programem na zwornikach, wysklepkach, z symbolicznym znaczeniem postaci patronów na ścianie wschodniej i z przedstawieniami w witrażach wschodniego okna. Szczegółowość opowieści i moralizatorska wymowa Ukrayżowania, a szczególnie Sadu czy przedstawień cnót i występków, ujawniały potrzeby nowej religijności w duchu afektywnej indywidualizacji i prywatyzacji religijnego przeżycia. Wydaje się, że z czasów ukończenia modernizacji tzw. trzeciego kościoła świętojańskiego może pochodzić również małe malowidło ścienne (na drugim od zachodu filarze północnego rzędu) ze sceną kanonicznego Ukrzyyzowania, odkryte 
w 2007 roku po zdemontowaniu nowożytnego ołtarza. Jego niewielkie rozmiary $(115 \times 80 \mathrm{~cm})$, wyodrębnienie malowana, pasmową bordiurą oraz fakt umieszczenia go zaledwie $30-40 \mathrm{~cm}$ nad gotycką mensą ołtarzową sugeruja pełnienie przez nie funkcji obrazu ołtarzowego (odpowiednika malowanego retabulum), zachowanego in situ. Podobne, niskie obrazy - retabula ołtarzowe ze sceną Ukrzyżowania na neutralnym tle znamy już w Europie z XIII stulecia. Te odkryte w toruńskiej farze, z modelowanymi w tynku i złoconymi nimbami, należy wiązać z obecnymi na terenach państwa zakonnego w Prusach wpływami sztuki czeskiej, która w dobie cesarza Karola IV przejęła bizantyjsko-włoską (pogiottowska) tradycję plastycznego modelunku walorowego i złoconych, plastycznych aplikacji opracowanych w zaprawie. Zarówno tzw. styl miękki malowidła, jak i mistyczny typ ikonograficzny postaci Chrystusa (z krwią wytryskującą z ran), plastycznie opracowane nimby, gruba linia konturu postaci asysty wskazuja, że powstało ono najpóźniej na początku trzeciej ćwierci XIV stulecia ${ }^{14}$.

Ci, którzy wznosili świątynię, chcieli nie tylko modlić się w niej, ale także pozostać w niej po śmierci i trwać - świadczyły o tym płyty nagrobne. Przykładem jest brązowa płyta nagrobna małżonków Małgorzaty i Jana von Soest (1358 rok), sprowadzona z Brugii przez radnego i burmistrza Jana von Soest (il. 11). Wierni trwali też na kontemplacji Męki Pańskiej, kulcie Eucharystii, na prywatnych modlitwach. Indywidualna i bracka nabożność stała się powszechnym zjawiskiem. Świadectwem jest krucyfiks z około 1360 roku, umieszczony w ołtarzu św.

14 Należy zwrócić uwagę, że malowidełko - szczególnie w opracowaniu postaci Chrystusa na krzyżu - nosi cechy stylu lat 40. i 50. XIV w. i można wskazać wiele analogii do niego w malarstwie witrażowym, ściennym, a szczególnie w iluminatorstwie. Słusznie zauważył ostatnio Juliusz Raczkowski, że wzorce tkwiły właśnie w malarstwie miniaturowym z I połowy XIV w. (J. Raczkowski, Najnowsze odkrycia w zakeresie gotyckiego malarstwa ściennego w Prusach $i$ ich znaczenie dla badan nad sz̨tukq regionu, [w:] Homo Creator et Receptor Artium. Ksiega pamiatkowa Ksiedzu Profesorowi Stanisławowi Kobielusowi ofiarowana, Warszawa 2010, s. 89-105). Można je odnaleźć jeszcze wcześniej, w czwartej ćwierci XIII w. Jednakże pożar świątyni i prace naprawcze oraz „italsko-czeskie” plastyczne nimby mogą wskazywać jako względny czas jego powstania lata po 1351 r., tj. kilka lat po usunięciu szkód po pożarze. Potwierdzeniem takiego datowania może być fakt, że na malowidle nie było śladów kopcia, który ujawniają prace konserwatorskie prowadzone obecnie w nawie południowej i na filarach korpusu. 
Krzyża, reprezentujący upodobanie do tzw. mistycznych Ukrzyżowań typu nadreńskiego ${ }^{15}$. W nurcie przedstawień określanych jako dewocyjne, o podobnym emocjonalnym oddziaływaniu na patrzacego, powstała figura Chrystus Maż Boleści (Vir Dolorum) (około 1420-1430 roku) w geście ukazywania ran (ostentatio vulnerum), z kaplicy Bożego Ciała. Jeśli przyjąć, że z toruńskiego kościoła świętojańskiego pochodzi rzeźba Chrystusa w Ogrójcu, z około 1400 roku, znana raczej jako rzeźba z kościoła w Malborku (Muzeum Zamkowe w Malborku), to byłby to wyśmienitej klasy przykład rzeźby dewocyjnej, zrodzonej z pobożności ukierunkowanej na Pasję Chrystusa. Spośród dzieł tworzących klimat kaplic użytkowanych do wspólnotowej dewocji należy wyróżnić figurę św. Barbary odkutą w wapieniu, pokrewną stylowi Pieknej Madonny z około 1390 roku. Bardzo reprezentacyjny charakter nadano płaskorzeźbionemu przedstawieniu św. Marii Magdaleny z pierwszej kaplicy po stronie południowej (po 1416 roku lub lata 20. XV wieku). Z kultem Najświętszego Sakramentu i przemianami architektonicznego wystroju światyni w latach 60.-70. XIV wieku wiąże się także rozbudowa zakrystii1 ${ }^{16}$. Urządzono ja jako kaplicę związana z kultem Najświętszego Sakramentu, a dokładniej - kaplicę Nowego Grobu Chrystusa ${ }^{17}$. Stała się ona jednocześnie miejscem czczenia relikwii świętych, przekształciła w miejsce modlitw i czuwań. Z koncepcją kaplicy Nowego Grobu Chrystusa korespondują przedstawienia na wspornikach, z wyobrażeniami Marii Bolesnej, Chrystusa Męza Boleści, umieszczonych naprzeciw siebie, najbliżej ołtarza, oraz świętych ustawionych parami na pozostałych wspornikach (Barbary i Katarzyny, Jana Chrzciciela i Jana Ewangelisty, Jakuba Apostoła i Jakuba Młodszego) (il. 12a, b, c, d). Ten program w sposób szczególny dopełniał obraz stanu świadomości społecznej i religijnej komuny miejskiej, który rekonstru-

15 E. Pilecka, Gotycki krucyfiks z. ottarza Świetego Krayża w kościele św. Jana w Toruniu, [w:] Album Amicorum. Między Wilnem a Toruniem. Ksiega pamiatkowa ofiarowana prof. Józefowi Poklewskiemu z. okazji 70-lecia urodzin i 45-lecia pracy naukowej, Toruń 2008, s. 257-271.

16 B. Zimnowoda-Krajewska, Zakrystia kościoła śmiętojanskiego - próba rekonstrukcï faz budowy, [w:] Dzieje i skarby kościoła świętojanskiego w Toruniu, s. 177-195.

17 Zob. E. Pilecka, Kościót pw. św. Jana Chraciciela $i$ św. Jana Ewangelisty w Toruniu, s. $163 \mathrm{i} \mathrm{nn}$. 
owaliśmy na podstawie przemian architektury i wystroju wnętrza świątyni od połowy do schyłku XIV stulecia.

„Budowanie” nowego kościoła farnego ponownie stało się wyrazem woli przetrwania i walki o prestiżowa pozycję wśród miast handlowych, gdy przystapiono do realizacji wysokiej hali korpusu kościoła św. Janów po II pokoju toruńskim. Miasto, chociaż otrzymało przywileje i nadania ziemskie za poparcie króla Kazimierza Jagiellończyka w konflikcie z zakonem, to jednak wyczerpane finansowo kosztami tej wojny nie miało funduszy na duże przedsięwzięcia budowlane. Bardzo chciało jednak dorównać gdańskiej świątyni Głównego Miasta - kościołowi Najświętszej Marii Panny. Żadne względy praktyczne nie warunkowały dwukrotnego podwyższenia wysokości budowli. Wyboru formy architektonicznej-wysokiej, jasnej hali i władczej „westwerkowej” wieży, dokonała silna, samorządna komuna w obliczu upadku władzy feudalnej zakonu, po pozbyciu się krzyżackiej zwierzchności.

Tę budowę, czy raczej rozbudowę, fary Starego Miasta realizowano z wielkim trudem, za wszelką cenę - używając rozbiórkowego materiału budowlanego, prowadząc prace w wielu fazach. Detale architektoniczne były odzyskiwane z wcześniejszego kościoła i najprawdopodobniej zbierane także z innych, bliżej nieokreślonych obiektów. Kompletowane doraźnie zespoły budowlane działały w krótkich odcinkach czasu i nie wykazywały się kunsztem. W 1472 roku w kronikach miasta odnotowano wymurowanie łuków sklepiennych przez mistrza Prokopa, co bywa traktowane jako zakończenie wszystkich robót budowlanych. Informuje o tym także napis zachowany na zachodniej ścianie nawy północnej: Im Jahre m.cccc Jar. Lxxiii am. abende. loren\%: ist. dis. Gewelbe Geschlossen (il. 13a, b, c, d). Zapewne prace ciagnęły się jednak jeszcze do początków XVI wieku i nigdy nie zostały ostatecznie zamknięte, co potwierdzają prowizoryczne szczyty wschodnie korpusu ${ }^{18}$ (il. 14a, b). Być może właśnie ze względów oszczędnościowych wysoką halę typu gdańskiego wzniesiono w ,archaicznej” konwencji artystycznej, wykorzystując dawne filary i tylko je nadbudowując. Jednak nie wszystkie rozwiązania należy zrzucić na karb

18 Eadem, Piętnastowieçna architektura kościoła św. Jana w Toruniu, „Acta Universitatis Nicolai Copernici. Zabytkoznawstwo i Konserwatorstwo”, 1987, t. 11, z. 161, s. 105-143. 
braków finansowych. W detalach - wałkowych służkach, wspornikach (z przedstawieniem karła, głowy króla, maski) - widać celową archaizację i nawiązanie do XIII-wiecznych form. Archaizacja podkreślano i unaoczniano długą tradycję kulturową społeczności miejskiej gromadzącej się w swym kościele farnym. I na tym etapie budowania nowej świątyni odwołano się, wprowadzając odpowiedni język form architektonicznych, do jej niemal trzechsetnego trwania. Generalnie całe rozwiązanie architektoniczne świadczy jednak o woli odrzucenia tradycyjnych rozwiązań i otwarciu na sztukę wielkiego Gdańska, o próbie twórczego wykorzystania pomysłów z miast nadbałtyckich.

Wystrój fary staromiejskiej stał się barwny i bogaty, ale też zatomizowany w licznych, autonomicznych kompartymentach. Praktyki religijne uprawiano z podziałem na grupy, skupiające się we własnych „kątach” kaplicowych aneksach i przyfiltrowych ołtarzach ${ }^{19}$. Światynia zapełniała się cechowymi i prywatnymi ołtarzami, figurami do prywatnej dewocji, tablicami wotywnymi, epitafiami. W późnym średniowieczu i w początkach epoki nowożytnej znajdowało się tu aż 18-20 ołtarzy (tylko trzy z nich zachowały swe pierwotne patrocinia: Bożego Ciała, św. Anny przy drugim filarze międzynawowym po stronie południowej i św. Barbary w czwartej kaplicy północnej). Istniejące do dziś zabytki, chociaż poprzestawiane w czasach nowożytnych, ukazują różnorodność gustów i artystycznych inspiracji, lokalną transformację i stylizację wzorów, a także zatomizowanie się komuny miejskiej, uprawiającej praktyki religijne z podziałem na grupy, skupiające się w swoich „kątach”. W nich gromadzono nowe dzieła sztuki, uzupełniające lub zastępujące starszy wystrój i odpowiadające aktualnym gustom. W specyficzny sposób zmieniały i „zagęszczały” przestrzeń świątyni. Do elementów związanych z liturgią należały ołtarze, które najczęściej nie zachowały się w stanie pierwotnym i na pierwotnym miejscu. Większość pochodzi z około 1500 roku. Obecny ołtarz główny - tryptyk św. Wolfganga, biskupa Ratyzbony (pierwotnie ustawiony przy zachodnim filarze południowego rzędu) - należy do dużej grupy późnogotyckich rzeźb, związanych z tzw. Mistrzem Ołtarza św. Wolfganga, kierującym toruńskim warsztatem, czynnym około 1495-1510 roku. Świadectwo wpływów południowoniemieckich stanowi także ołtarz Zaśnięcia Najświętszej

19 Zob. Sztuka średniowiecz̧na, s. 159 i nn. 
Marii Panny. Reliktem jednego z ołtarzy jest skrzydło ze scenami Zwiastowania, Narodżin, Obrzezania z końca XV wieku. Mogło należeć do nastawy ołtarzowej określanej w źródłach jako Parantele Christi. Z późnogotyckim ołtarzem głównym należy łączyć dwie figury świętych patronów kościoła - św. Jana Ewangelisty (z 1497 roku) i św. Jana Chrzciciela (w Muzeum Okręgowym w Toruniu). Być może z górnej kondygnacji niezachowanego retabulum pochodzi figura Chrystusa Zmartwychwstałego, zaopatrzona na cokole w datę 1497. Nie można wykluczyć używania jej do rytu elevatio ymaginis salvatoris (wciagania w trakcie nabożeństwa ku górze ponad sklepienie - „do Nieba”) w święto Wniebowstapienia Chrystusa. Brak jednak przekazów o praktykowaniu w Toruniu tego zwyczaju liturgicznego, który był związany raczej ze środowiskami katedralnymi, kolegiackimi i klasztornymi. Według opisu Strzesza z 1671 roku w Kaplicy Kupieckiej stał stary ołtarz (altare vetustum) z retabulum Czternastu Wspomożycieli. Z nim jest łączona figura Chrystusa Bolesnego (około 1510-1520 roku), stojąca dziś w tzw. Kaplicy Kopernika (dawnej Kupieckiej). Z klimatu religijnego wynika jej dość rzadkie ujęcie ikonograficzne; nacisk położono na moment biczowania, a nie na eucharystyczne treści. Była ona inspirowana rzeźbą szwabską Hansa Multschera i północnych Niemiec. Z tego czasu, ale z nieznanej większej całości, pochodzi figura Archanioła Gabriela $z$ grupy Zwiastowania. Uczniowie bądź pomocnicy Mistrza Ołtarza św. Wolfganga wykonali figurę Boga Ojca z przedstawienia Tronu Łaski, które było umieszczone zapewne $\mathrm{w}$ predelli lub zwieńczeniu nieistniejącego ołtarza, a także figury św. Wawrzyńca i św. Wolfganga (Muzeum Okręgowe w Toruniu). Do prywatnych fundacji w farze należało malarskie epitafium kasztelana lądzkiego Jana Kota (krótko po 1454 roku, zaginione podczas II wojny światowej). W kościele św. Janów znajdowały się też przez pewien czas dwa wspaniałe obrazy o charakterze wotywnym bądź epitafijnym: Zdjeccie z krzyża (k. XV wieku) i Biçowanie (k. XV wieku), zanim przeniesiono je do Muzeum Diecezjalnego w Pelplinie. (Ich pierwotnym miejscem przeznaczenia mógł być kościół pw. św. Wawrzyńca). Nowy kształt światyni oraz elementy wyposażenia sa świadectwem tego, że ambicje polityczne elit były manifestowane równolegle z artystycznymi, często przerastającymi możliwości gminy. I wreszcie, 22 września 1500 roku, ku chwale Boga, świętych patronów ukończonego kościoła, rady i miasta, odlano dzwon Tuba Dei - Traba Boga (il. 15). Umieszczono 
na nim inskrypcję z datą (datę można odczytać także jako 1522), a przede wszystkim postacie czczonych od dawna patronów: św. Jana Chrzciciela, św. Jana Ewangelisty, św. Barbary i św. Katarzyny. Tuba Dei miał strzec miasta i oznajmiać najważniejsze wydarzenia.

Jakkolwiek nie ocenialibyśmy architektury i wyposażenia fary Starego Miasta Torunia w okresie średniowiecza, jedno pozostanie wartością niezaprzeczalną - od pierwszego „oratorium” do późnogotyckiej wysokiej hali komuna miejska pozostawiała tu artystyczny zapis swej egzystencji. Ciagłe budowanie gwarantowało jej trwanie. Budowanie było nie tylko przekształcaniem architektonicznych postaci budowli, ale też narastaniem i nawarstwianiem treści duchowych. I choć stara świątynia parafialna nie reprezentuje architektonicznego modelu średniowiecznej katedry, to pokładane w niej przez pokolenia nadzieje, przypisywane jej wartości, czynia ja godną stołecznej pozycji w ramach diecezji.

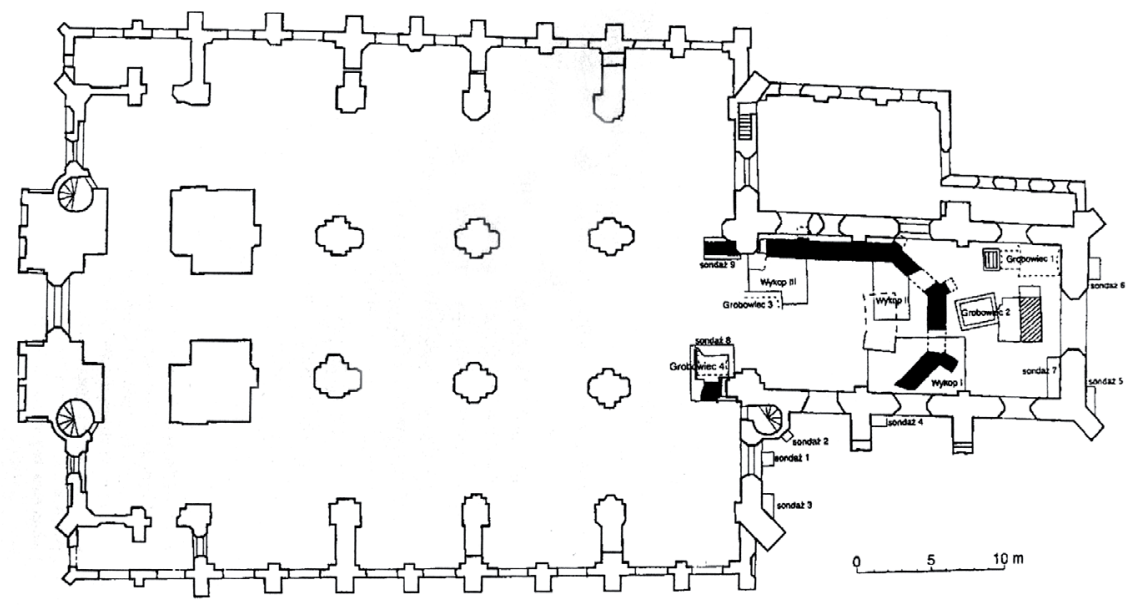

Il. 1. Archeologiczne relikty pierwszego kościoła św. Jana w Toruniu - według Lidii Grzeszkiewicz-Kotlewskiej 


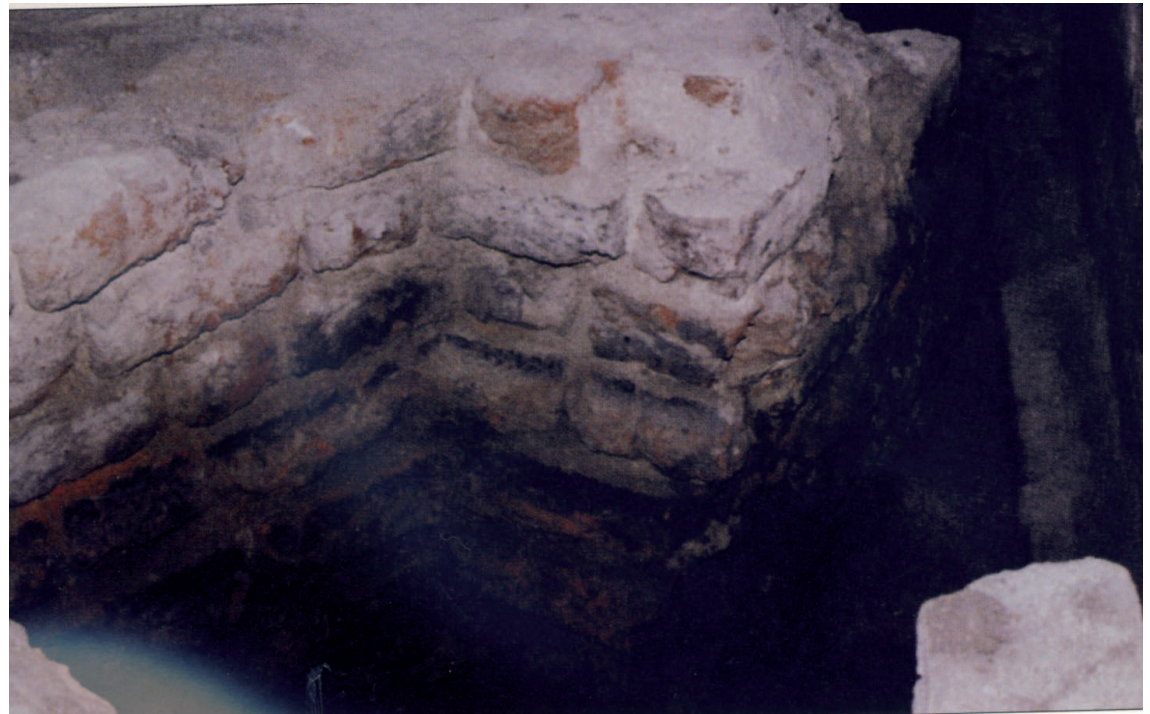

Il. 2. Gzyms cokołu z profilowanej i glazurowanej cegły, obiegającego I kościół św. Janów (autor wszystkich fot. A. Skowroński)

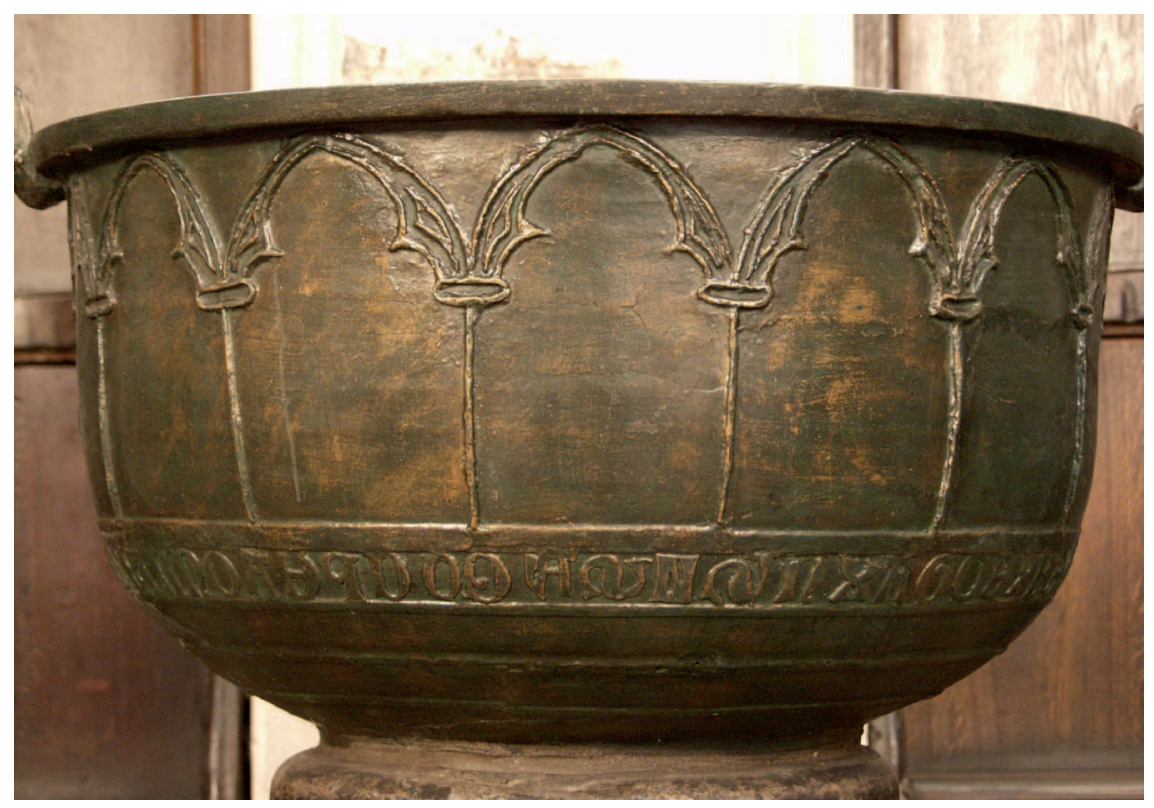

Il. 3. Chrzcielnica z wyposażenia najstarszej świątyni pw. św. Janów 
a)

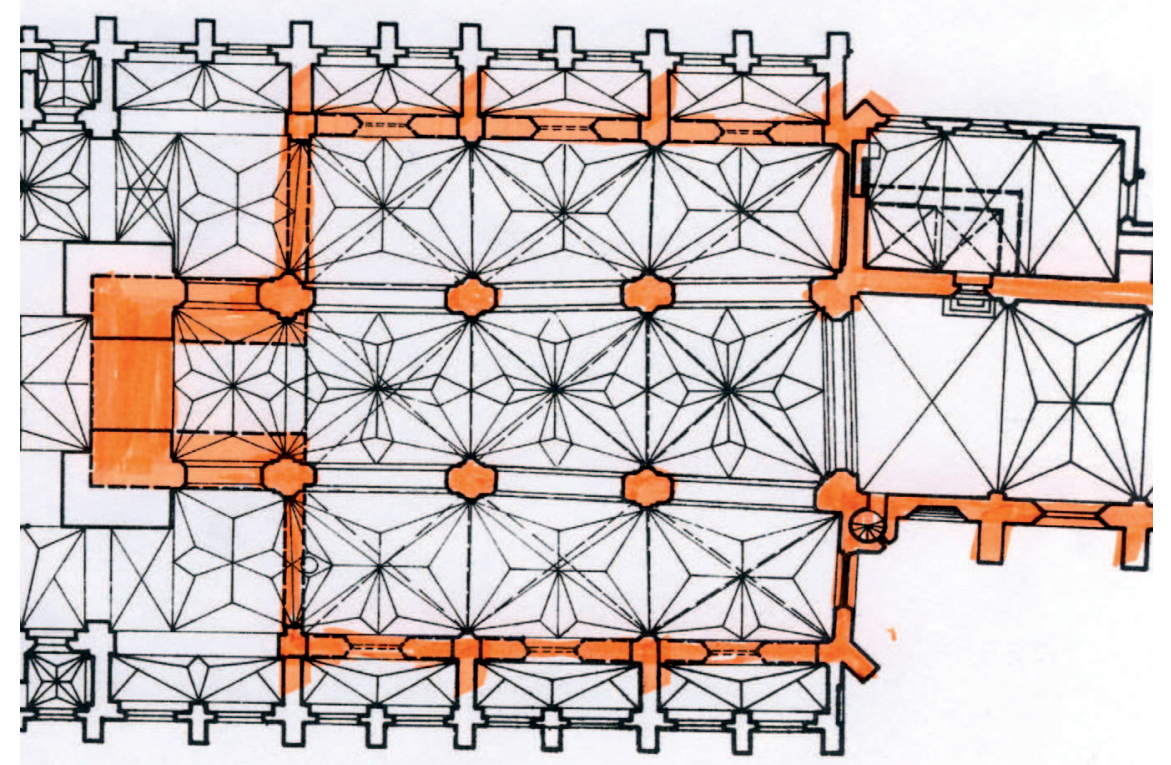

b)

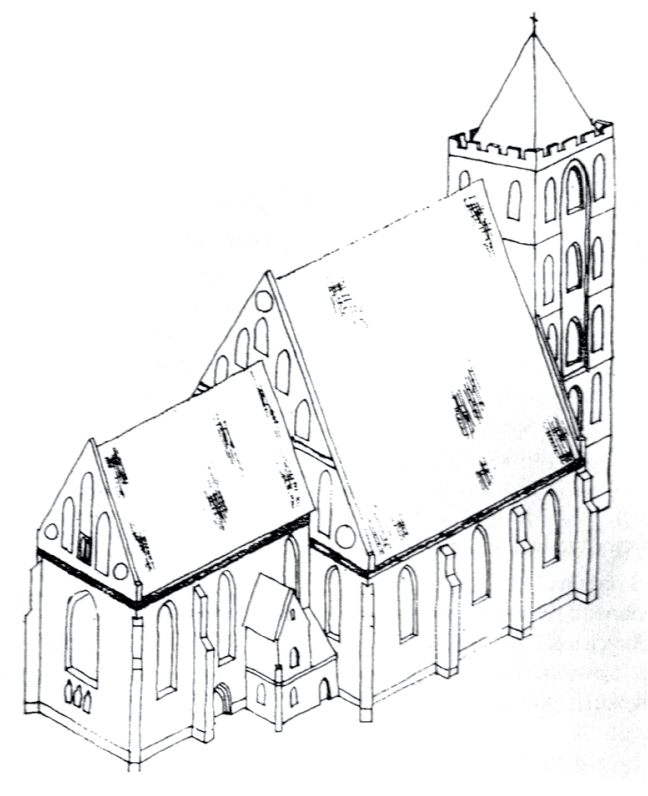




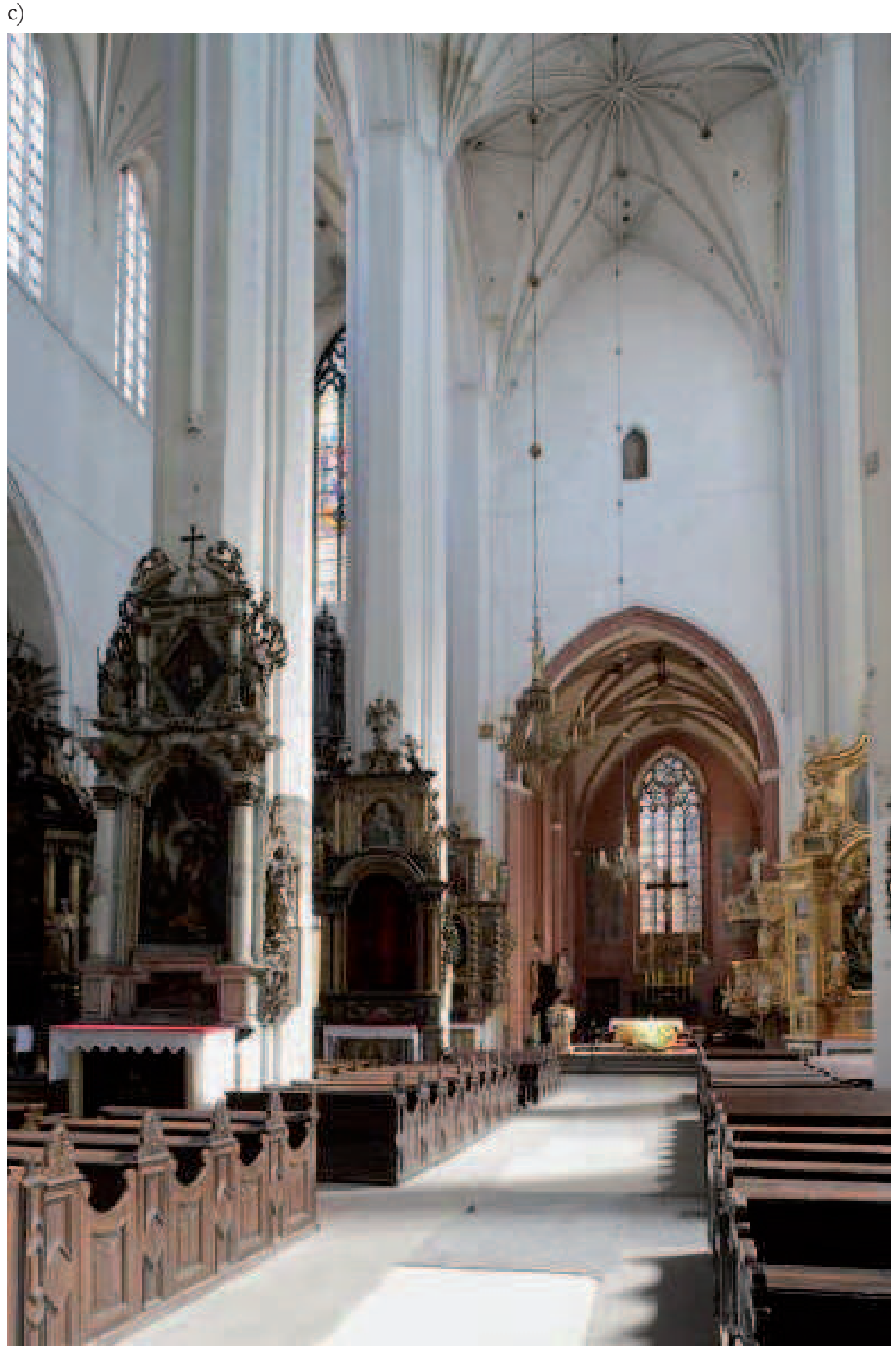


d)

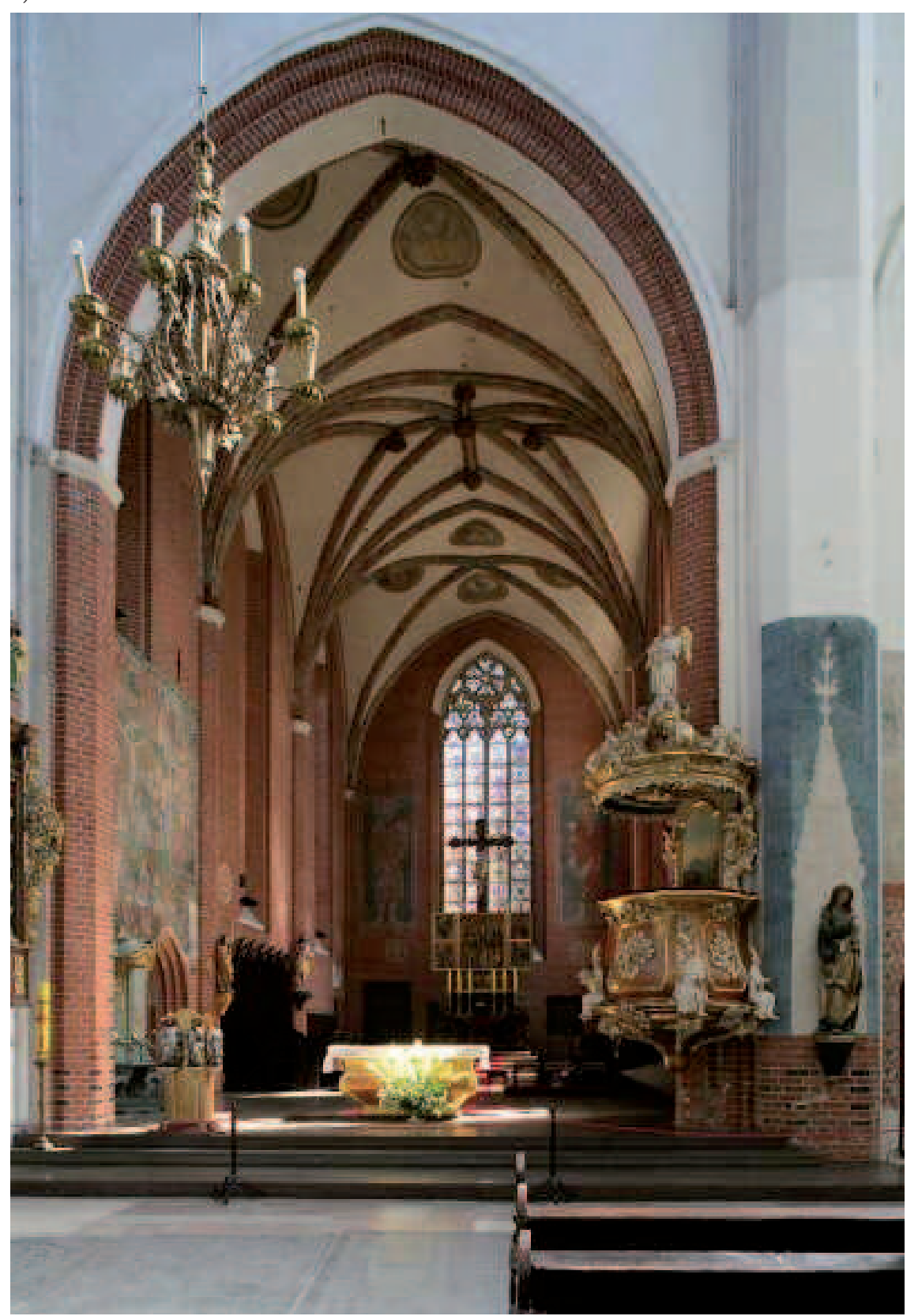

Il. 4a, b, c, d. Rzut kościoła II i widok wnętrza obecnego korpusu i chóru 


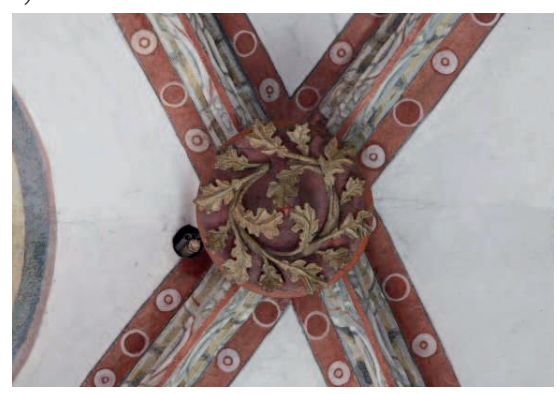

c)

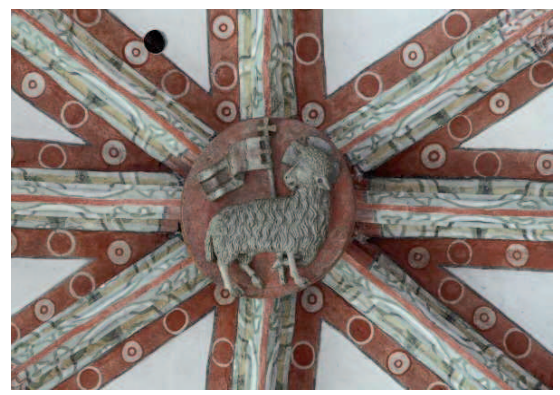

Il. 5a, b, c, d. Zworniki sklepienne w chórze kościoła św. Janów

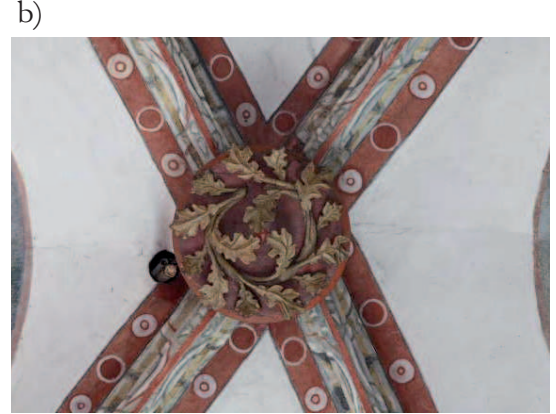

d)

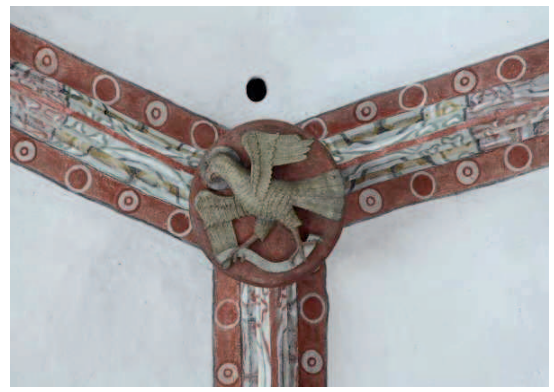

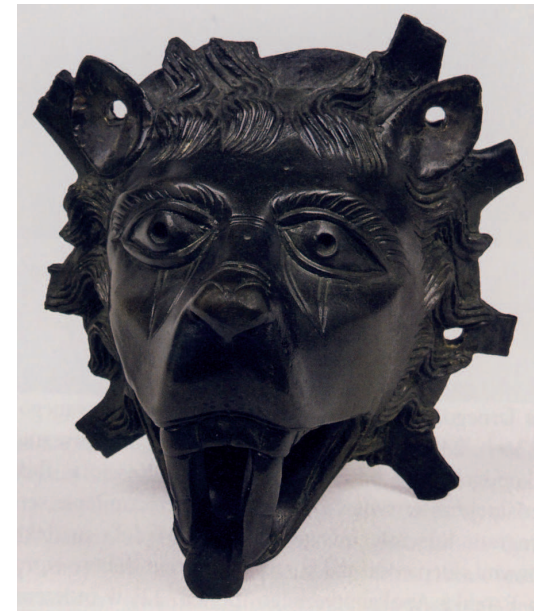

Il. 6. Kołatka z kościoła św. Janów 


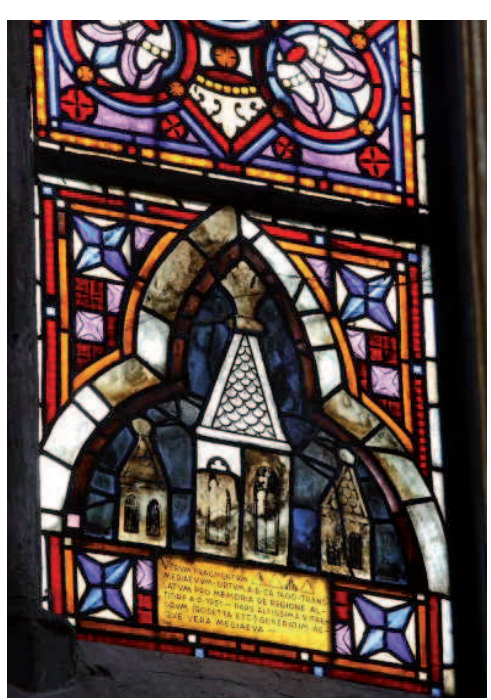

Il. 7. Fragment witraża z chóru kościoła św. Janów
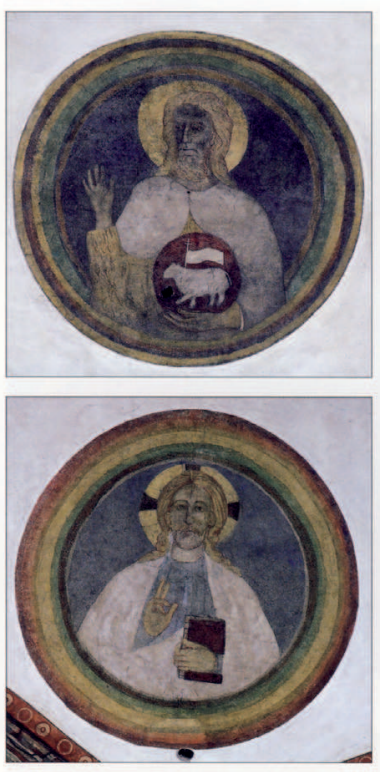

Il. 9. Malowane medaliony na wysklepkach chóru kościoła św. Janów
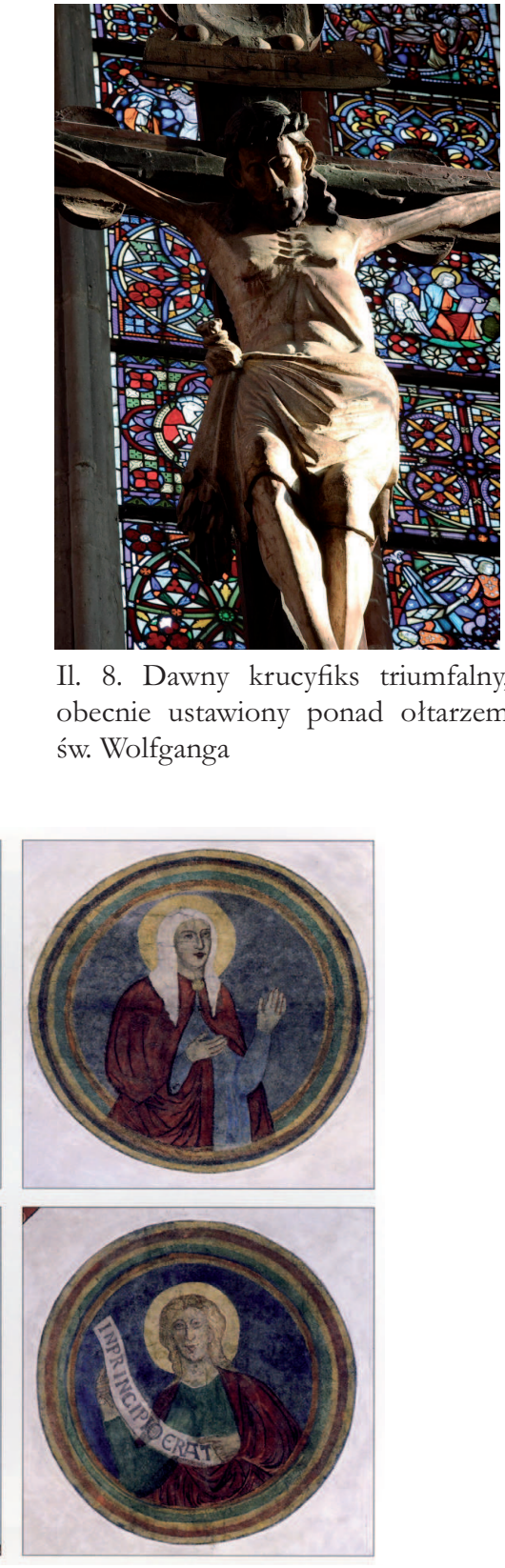

Il. 8. Dawny krucyfiks triumfalny, obecnie ustawiony ponad ołtarzem św. Wolfganga

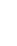




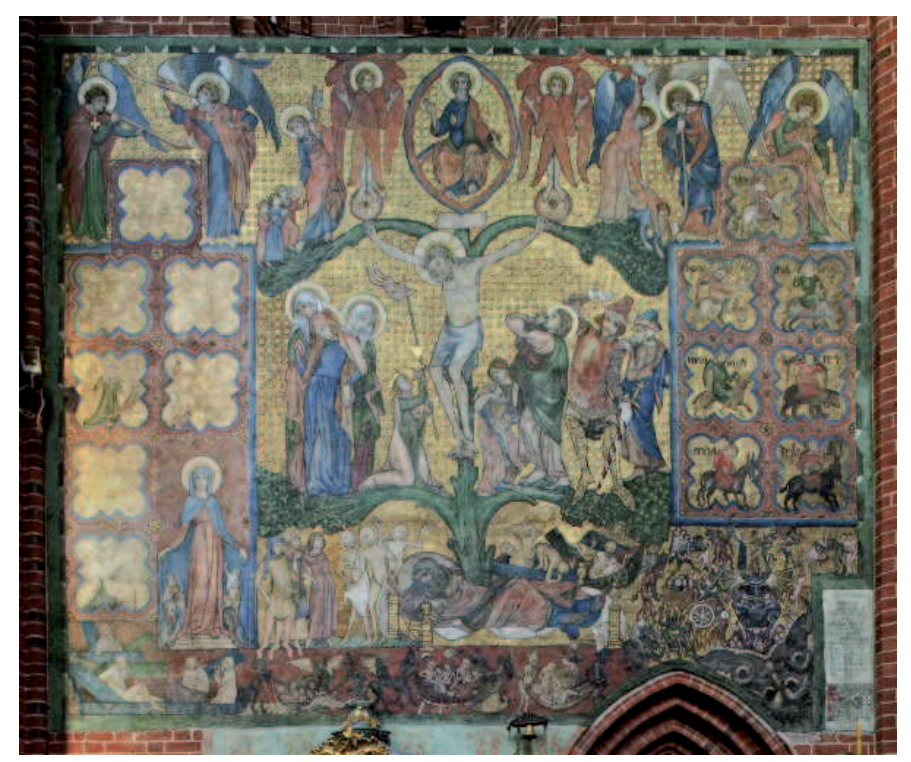

Il. 10. Malowidło z Ukrzyżowaniem na Drzewie Życia

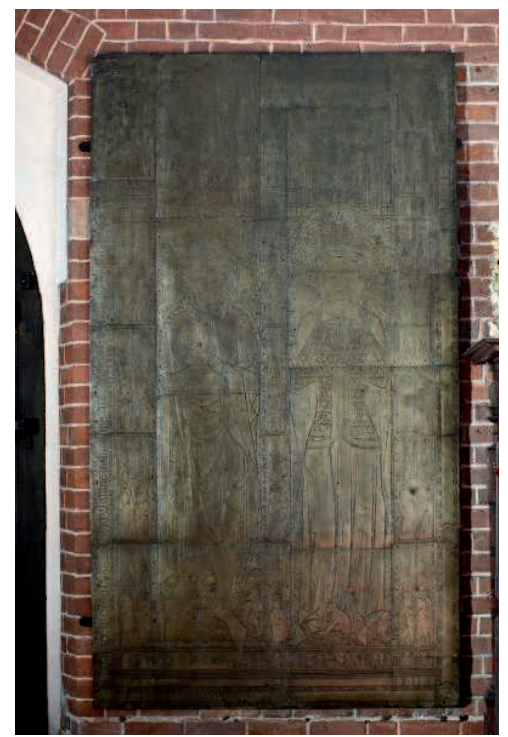

Il. 11. Płyta nagrobna małżonków Małgorzaty i Jana von Soest z kościoła św. Janów 


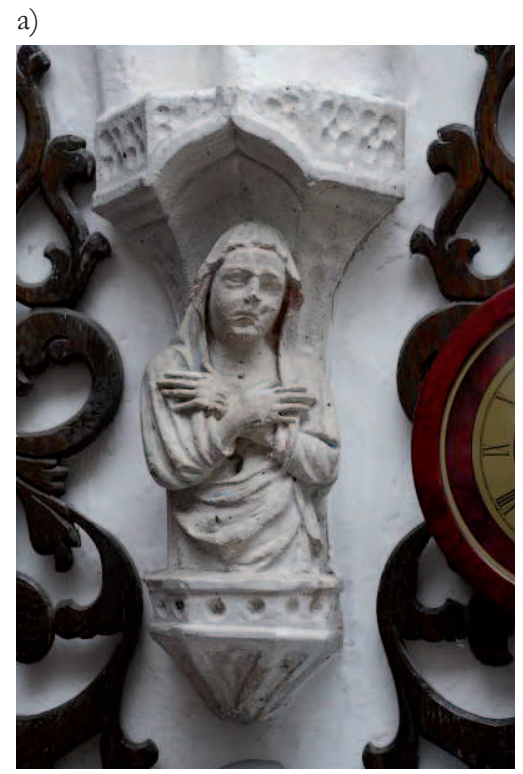

b)

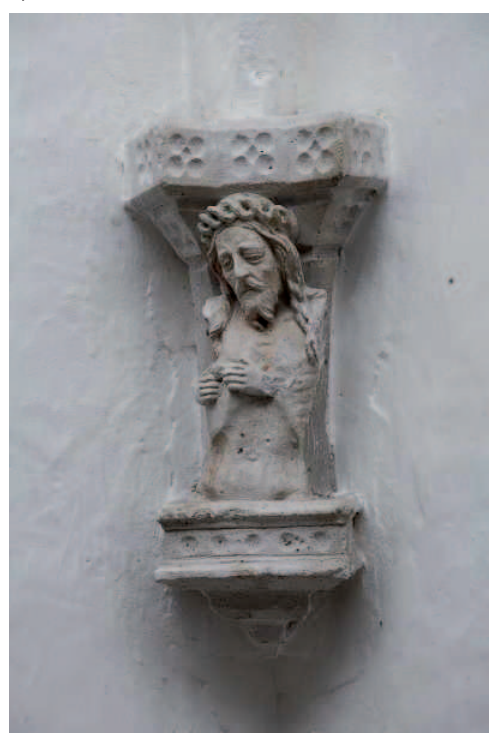

c)

d)
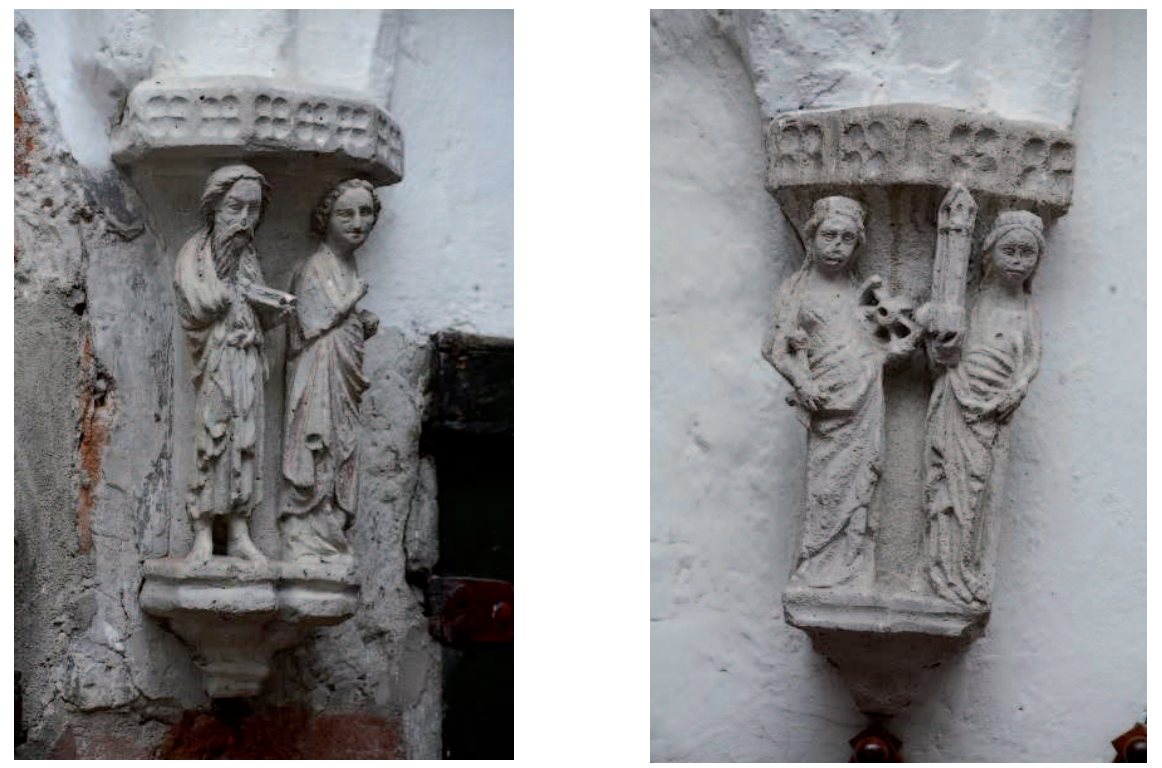

Il. 12a, b, c, d. Konsole sklepienne z zakrystii kościoła św. Janów 


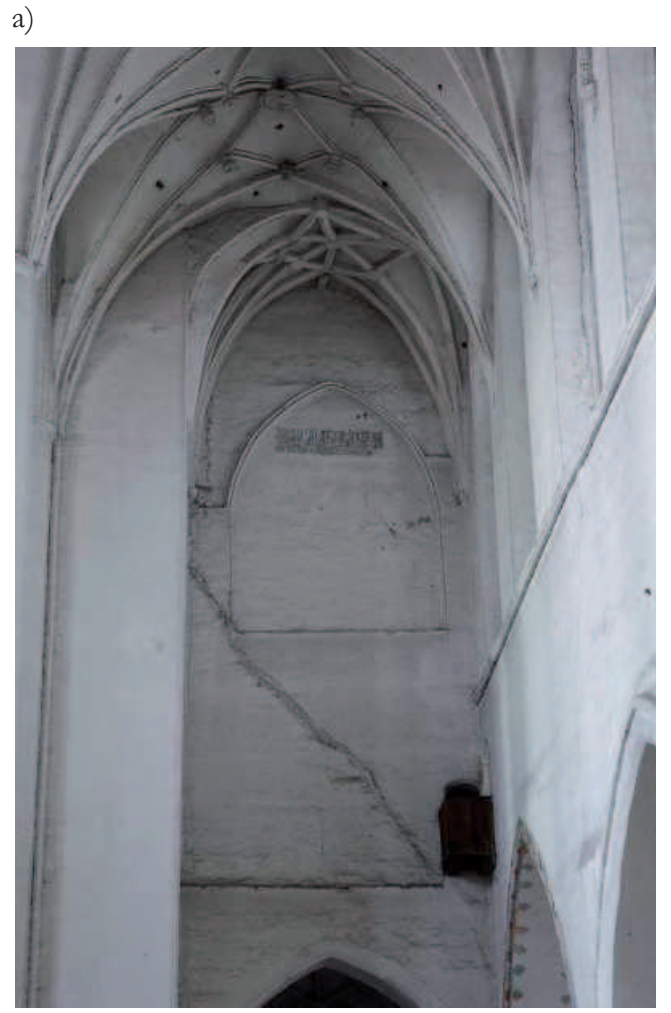

b)

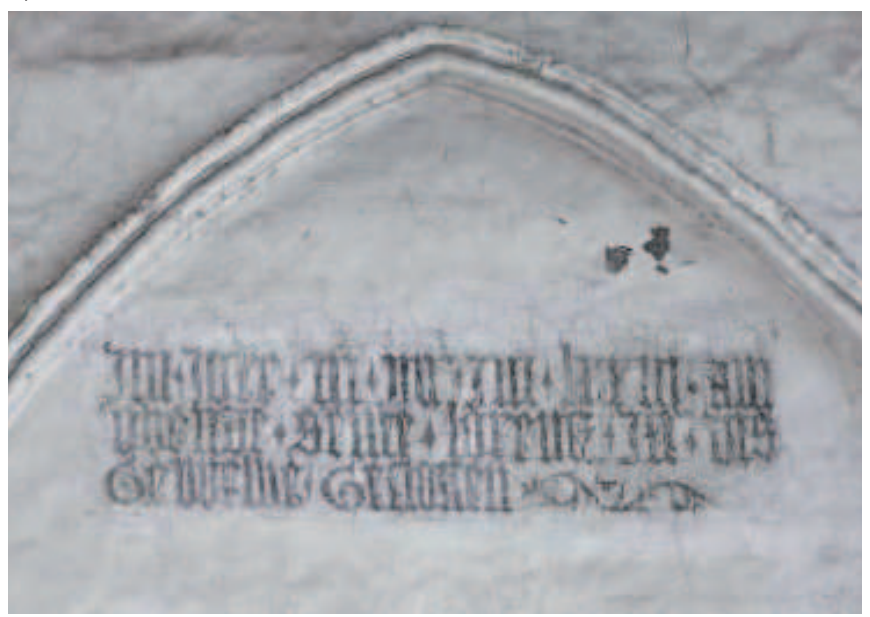




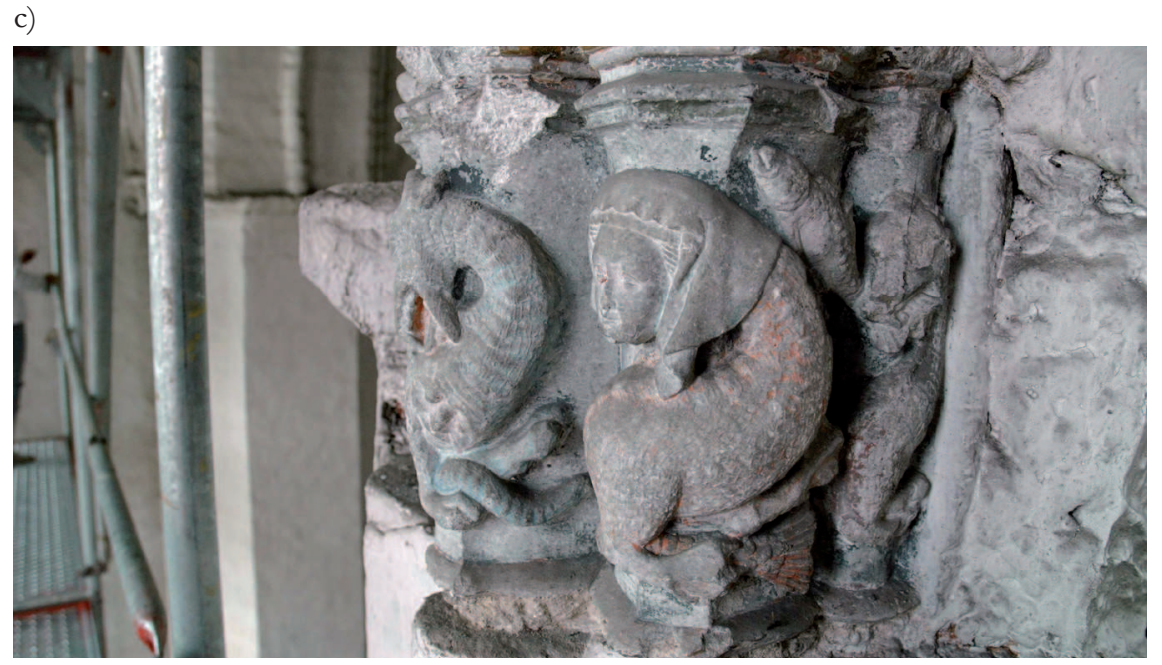

d)

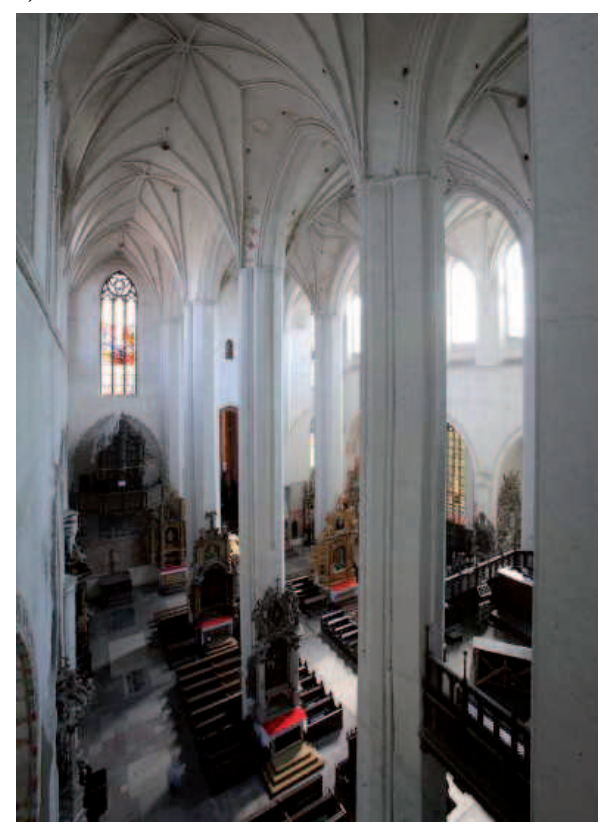

Il. 13a, b, c, d. Napis z datą 1472 na ścianie zachodniej nawy północnej, wtórnie użyta konsola sklepienna i wnętrze wysokiej hali 
a)

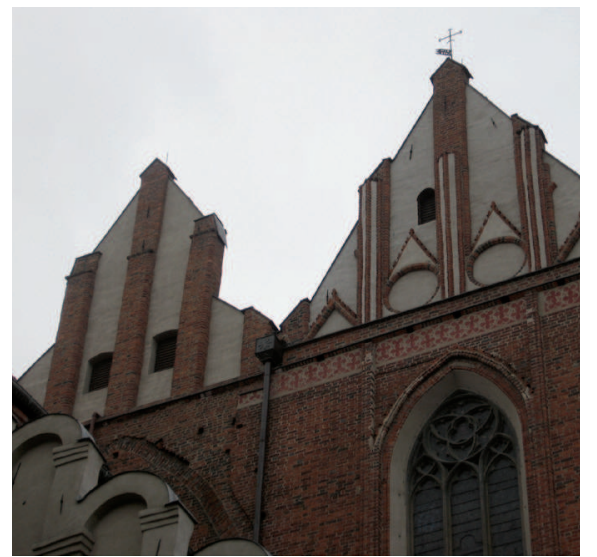

b)

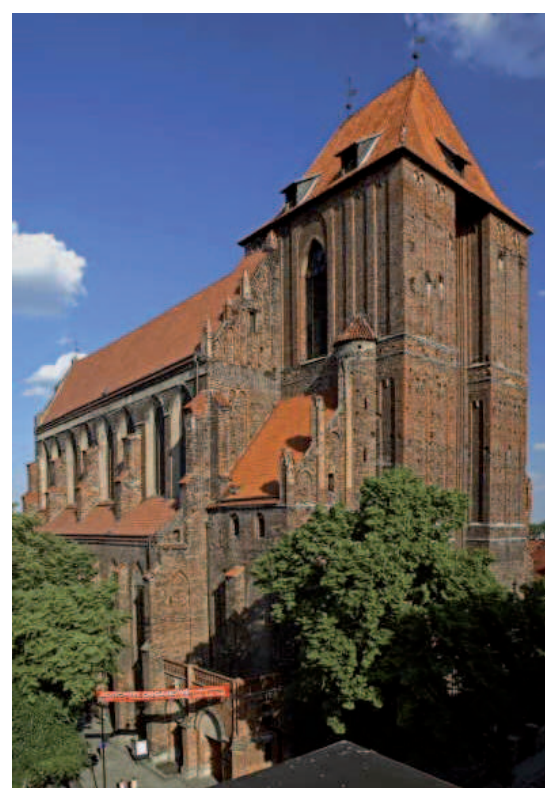

Il. 14a, b. Widok szczytów kościoła od wschodu i bryły od zachodu

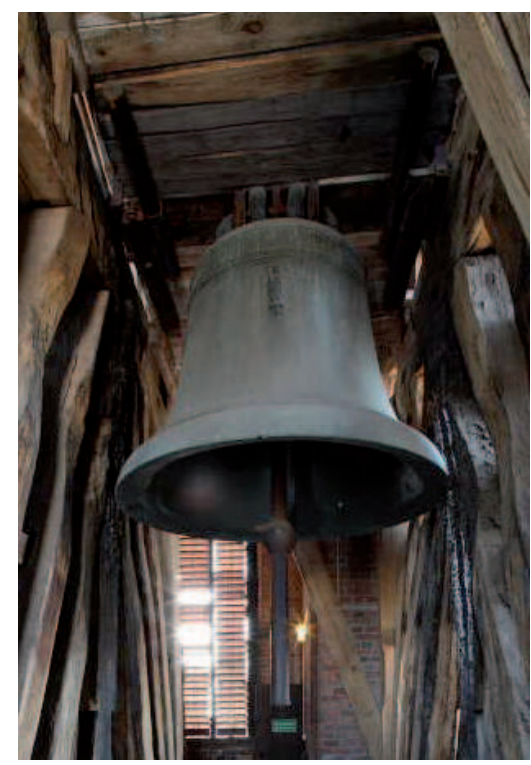

Il. 15. Dzwon Tuba Dei 


\section{Summary}

\section{Building and lasting - the medieval history of Old City of Torun parish church, current cathedral of Sts. John the Baptist and John the Evangelist}

The parish church of Sts. John the Baptist and John the Evangelist in Old City of Torun has been witness to both turbulent historical events and artistic tastes of the dwellers. Every phase of the building of the church may be interpreted in such a way. However, it can be also assumed that during all phases of forming of its material substance (from 1236 until the beginning of the sixteenth century) the more profound meaning was manifested. This was the will to survive and to last, the will of the Church not only considered as a building, but also as an institution which unites and represents the city commune. For this aim the artistic language of the "image" was used in architecture and interior decoration. The commune and the Church exhibited strong cohesion - the interdependent "coherent configuration."

From the erection of the first "oratory" until the construction of the lategothic high hall church the city commune was leaving an artistic imprint of its existence on the architecture and interior of the building. The continuous transformation of the church was its goal, as the church became an evidence and guarantee of the city's constancy. The building process meant searching for the proper means of expressing the variable religious and spiritual ideas, as well as aspirations of social classes and ruling elites. 